\title{
Fairy Tale Form Spoken to Written in the Perspective of Readingless Teenager
}

\author{
Wicahyanti Rejeki* \\ Graduate School \\ Universitas Negeri Yogyakarta \\ Yogyakarta, Indonesia \\ wicahya16@gmail.com
}

\author{
Suminto A. Sayuti \\ Graduate SchooL \\ Universitas Negeri Yogyakarta \\ Yogyakarta, Indonesia \\ suminto_sayuti@uny.ac.id
}

\begin{abstract}
Fairy tales are imaginary stories that are not bound by place and time told for generations. This research aims to describe of teenager aged 13-15 years in Magelang on the elements of plot, character, style, and theme fairy tale "Burung-burung Memilih Raja" and the affecting factors that influence their response to this fairy tale. It is a method of concurrent embed model combination. The research subjects are the grade VIII students in one learning group of the four schools in Magelang. The data source is the fairy tale entitled "Burung-burung Memilih Raja" retold by Nukila Amal, the result of the response to this fairy tale, and the factors that influence the responses. The research data was obtained through questionnaires. The data were analyzed quantitatively and qualitatively. The results show that in one side, the fairy tale "Burung-burung Memilih Raja" got the positive responses from the readers. But, in the other hand there are contradictions to these results. Internal factors consist of limited literary reading experience and limited experience of hearing or watching fairy tales. External factors consist of motivation from parents to read literature, the influence of friends who are not accustomed to read literature, and the influence of television and social media.
\end{abstract}

Keywords - fairy tale, teenager, reception, factors.

\section{INTRODUCTION}

Children must be raised so that they will fall in love with virtues and hate bad things through stories, music, and art. Thus the expression of Plato (in Killpatrick, 1994:23). The statement confirms that the story plays an important role in instilling children's morale. Parents do not have to always tell that something is good or bad to do. However, through stories that develop children's imagination, they will get the moral message.

The tradition of storytelling that used to be often used as a lullaby for children provides many benefits. In addition to delivering moral messages that can form praiseworthy characters, fairy tales bring the relationship between storytellers and children, stimulating children to be creative and imaginative, enrich vocabulary, and improve communication skills through sound processing and expression processing.

Through stories that have a variety of themes, such as patience, affection, responsibility, and social, children can take lessons in humanity. Thus, literature (in this case a fairy tale) has an important role in the development of a child's personality. This certainly cannot be separated from the literary function of dulce et utile (entertaining and useful) expressed by Horatius (in Teeuw, 1984:183). The function of entertaining (dulce) means that literature gives pleasure to the reader so that the reader is interested in always reading literary works. The useful function (utile) means that literature provides a moral inculcation so that the reader can emulate the positive things of literary work.

The presence of the reader is very necessary in appreciating literary works. This is because the significance of literary works exists with the presence of readers who provide responses or receptions. Junus (1985:1) suggests the nature of literary reception is the meaning by the reader of literary works so that they can give a reaction or response. Segers (2000:35) suggests that reception aesthetics are teachings that investigate literary texts on the basis of the reader's reaction to literary texts.

Research on responses to fairy tales needs to be done because research so far has focused more on analyzing literary works without involving readers' responses. In addition, there are not many observers of Indonesian children's literature.

\section{METHOD}

Research conducted on the fairy tale "Burung-burung Memilih Raja" ("BMR") as an effort to determine the ability to respond to the fairy tale of students of class VIII in the City of Magelang. This fairy tale is a part of 35 folklore contained in the book Dongeng Negeri Kita published in 2015 by the Publisher of Padasan and Lembaga Seni dan Sastra Reboeng. Based on its contents, this tale corresponds to the age of the respondent who is 13-15 years old - a teenager who is in a transition period between children and adults. In addition, the narration done by Nukila Amal uses a variety of literary languages that are light, rather humorous, but satire, different from fairy tales in general.

The study uses a combination of concurrent embed models. The steps in the study include three stages, namely planning, implementing, and analyzing data. The data source of the research is the fairy tale ("BMR") retold by Nukila Amal and the results of the questionnaire. The number of students in each study group is as follows. SMP Negeri 1 Magelang consists of 28 students, SMP Negeri 6 Magelang consists of 31 students, SMP Negeri 13 Magelang consists of 29 students, and SMP Pentekosta consists of 31 students. Thus, respondents numbered 119 students.

The research instrument uses open and closed questionnaires. An open questionnaire in the form of a questionnaire that is used to determine the readers responses freely. This is because the respondent answers in his own sentence. The questionnaire was closed in the form of several questions with alternative answers provided. 
Respondents choose one of the answers by putting a check mark $(\checkmark)$ in the column provided.

Data analysis was carried out quantitatively and qualitatively. The activity carried out in this data analysis is to make tabulation of data according to groups. The data source is carefully examined for further interpretation according to the problems discussed in the research with literary reception theory and the elements of fiction prose builders.

\section{THE RESULT AND DISCUSSION}

The reception or response to the plot elements, characters, style, and theme of the fairy tale "BMR" in this study can be seen from the following table.

Table 1. Reader's Reception Results for Plots, Characters, Styles, and Themes in the Fairy Tale "BMR"

\begin{tabular}{|c|c|c|c|c|c|}
\hline No. & STATEMENT & $\mathbf{S A}$ & $\mathbf{A}$ & D & SD \\
\hline & Plot & & & & \\
\hline 1 & $\begin{array}{l}\text { Beginning of the } \\
\text { story makes me } \\
\text { want to know the } \\
\text { sequel. }\end{array}$ & 56 & 58 & 4 & 1 \\
\hline 2 & $\begin{array}{l}\text { There is a } \\
\text { surprising part in } \\
\text { the series of } \\
\text { stories. }\end{array}$ & 37 & 69 & 12 & 1 \\
\hline 3 & $\begin{array}{l}\text { The ending is not } \\
\text { easy to guess. }\end{array}$ & 72 & 12 & 12 & 23 \\
\hline \multirow[t]{2}{*}{4} & $\begin{array}{l}\text { Plot of a fairytale } \\
\text { according to my } \\
\text { expectations. }\end{array}$ & 13 & 71 & 31 & 4 \\
\hline & Figure and Chara & ter & & & \\
\hline 1 & $\begin{array}{l}\text { The characters' } \\
\text { characters are } \\
\text { clearly described. }\end{array}$ & 28 & 73 & 16 & 2 \\
\hline 2 & $\begin{array}{l}\text { Characters are } \\
\text { similar to human } \\
\text { life. }\end{array}$ & 37 & 63 & 15 & 3 \\
\hline 3 & $\begin{array}{l}\text { Characters can } \\
\text { inspire readers to } \\
\text { do good things. }\end{array}$ & 32 & 59 & 24 & 4 \\
\hline \multirow[t]{2}{*}{4} & $\begin{array}{l}\text { Prominent figures } \\
\text { and characters in } \\
\text { accordance with } \\
\text { my expectations }\end{array}$ & 11 & 73 & 31 & 4 \\
\hline & Style & & & & \\
\hline 1 & $\begin{array}{l}\text { Style (the specific } \\
\text { language used by } \\
\text { the author) helps } \\
\text { me understand the } \\
\text { story better. }\end{array}$ & 48 & 64 & 7 & 0 \\
\hline 2 & $\begin{array}{l}\text { Style can develop } \\
\text { my imagination. }\end{array}$ & 48 & 60 & 10 & 1 \\
\hline \multirow[t]{2}{*}{3} & $\begin{array}{l}\text { Style according to } \\
\text { my expectation. }\end{array}$ & 33 & 76 & 9 & 1 \\
\hline & Theme & & & & \\
\hline 1 & $\begin{array}{l}\text { Themes are found } \\
\text { in the lives around } \\
\text { us. }\end{array}$ & 20 & 69 & 27 & 3 \\
\hline
\end{tabular}

\begin{tabular}{lllllll}
\hline 2 & $\begin{array}{l}\text { Themes are able } 22 \\
\text { to express the }\end{array}$ & 67 & 27 & 3 \\
truth of the & & & & \\
author's ideas, \\
attitudes, and \\
outlook on life.
\end{tabular}

SA: Strongly Agree, A: Agree, D: Disagree, SD: Strongly Disagree

From this table it is known that the majority of respondents chose the strongly agree (SA) and agree (A) options for all statements. This shows that in accordance with predetermined criteria, the reader gives a positive response to the plot elements, characters, styles, and themes in the fairy tale "BMR".

The fairy tale "BMR" puts forward the search for the identity of Cala Ibi from the beginning to the end of the story. The plot used in this fable is chronological, single, tight, and closed. Chronological means in this fable consists of the beginning-middle-end. Single means that this fairy tale only has a plot that is primary like a short story. Tight means it is not possible to be interleaved with other plots. At the end of the story the author does not submit a solution to the reader, so it includes the type of closed plot. The presentation of this type of plot is in line with the distribution of plot types by Sayuti (2017:92).

The majority of readers consider the beginning that makes you want to know the continuation of the story contained in the following quote.

"My dear birds, today's deliberation of the birds is in the context of choosing the king of birds. All birds of any type are entitled to participate. You see, until now none of us has ever been able to fly to the sky. Well, in the election of this leader, whoever managed to fly to touch the sky and bring home a bit of the skin of the sky, he was crowned king." (Kristanti \& Pinurbo, 2015: 45)

The majority of readers rate the surprising part contained in the following quote.

"Sky, let's sky. Never go home before the sky! "Exclaimed Cala Ibi to the two eagles. With his agility he then displayed various maneuvers: flying back and forth, flying right and left, up and down, a happy somersault. The two eagles beneath him stared with their gaping beaks and eyes squinted by the sun's glare. (Kristanti \& Pinurbo, 2015: 48)

Readers find this part surprising because in the previous part of the story Cala Ibi is portrayed as a character who does not talk much and tends to think more often than expressing feelings expressively. However, in this section, Cala Ibi is agile, and even tends to 'show off' his flying skills.

... From up here, the king's throne and all the beautiful nests no longer have any meaning. Suddenly he flinched, who knows how long he was just floating with wings flapping, who knows exactly when he had stopped moving up and down. What is clear is that he feels light and unbelievably light and spacious. Having the chance to feel the sky for a moment, become the sky, even if only for a 
moment, is enough for him. What he brought home was not only the sky, but the entire sky. (Kristanti \& Pinurbo, 2015: 49)

In this section there is another attitude change from Cala Ibi. He who had been cheerful, bragged, and ambitious to win the race, at the height of the sky no longer felt that. Cala Ibi feels that he is nothing.

The majority of readers rate the end of the story that is predictable is found in the following quote.

... From the hole, the Cala Ibi bird observes the Goroko moving more slowly, until one day it no longer moves. After making sure the bird was asleep, the Cala Ibi bird tiptoed and he quickly flew out of the rat hole. (Kristanti \& Pinurbo, 2015: 51)

This part is easy to guess because there has been a skew of the imagination of the reader from the beginning of the story. Cala Ibi is portrayed as a figure who has a lot of sense (from carrying mahogany tree bark which will be recognized as a piece of sky to hitchhike riding on the back of Taong without being noticed). So, when Cala Ibi is in a position of urgency, he will find a way to escape.

Based on the explanation, it can be seen that there are intertwined stories related to causation such as the definition of the plot according to Stanton (1965:14). The beginning of this fairy tale is when the cockatoo opens its deliberations and announces that there will be an election for the king of birds through a contest. The middle part is when Cala Ibi can still fly swiftly at high altitude, while many other birds have given up or feel exhausted. The final part is when Cala Ibi managed to escape from Goroko's custody.

From these parts it is known that the initial part contains an exposition or exposition which gives information to the reader. The middle section contains sources of story instability, and the final section is the climax of the story and its completion. This is consistent with the theory put forward by Sayuti (2017:80) regarding the plot structure.

The majority of readers rate the plot in the fairy tale "BMR" as expected because the plot is clear, interesting, and intriguing, as in the following opinion quote.

Plot with clear forward flow makes it easy for readers to understand (MDK)

The series of stories is interesting and clear (FNP)

Make me curious to know the continuation of the story (ECR).

The characters in this fairy tale are characters who stimulate the reader's imagination because physically, the characters are not found in real life. However, the characters attached to the characters are often found in daily life. Cala Ibi is described as a quiet figure, thinker, unyielding, and smart as well as cunning. Goroko is described as a careless character. Parrot described as a character wise and charismatic. Elang Darat and Elang Laut are weak defenders. While other large birds become figures who try to uphold the truth according to the agreed forest law. These characters are close to the life of the reader so that they are easily connected with the reader's experience.

The characters shown are not all black-and-white characters like most fairy tales. The Cala Ibi figure is shown to have a combination of good and bad characters. That is, there is a development or change in character. Cala Ibi, who was originally described as quiet, turned into arrogant showing off his toughness in the highest sky, then turned to be humble when he realized the absurdity of his existence.

The majority of readers choose Cala Ibi as an inspirational figure because Cala Ibi is unyielding, clever, and humble as shown in the following opinion quote.

Cala Ibi is not easily discouraged even though his body is small. (AOD)

The clever bird Cala Ibi, has not lost his mind. (MA)

Cala Ibi is not arrogant despite winning the race. (FDA)

The majority of respondents chose Goroko as a non-inspirational figure. Goroko was chosen as a noninspiring figure because he neglected his duties as shown in the following respondents' opinions.

Goroko is not responsible (ALF)

Goroko did not carry out the mandate properly (JRF)

Goroko can't hold trust (ITA)

Although Cala Ibi was chosen as a figure that inspires readers, some readers also choose Cala Ibi as a figure who does not inspire. Respondents chose Cala Ibi as an uninspirational figure because he was not responsible and cheated. This is seen in the following respondents opinion excerpts. (BT)

Cala Ibi does not dare to face problems, prefers to run.

Cala Ibi was cunning, not admitting he was riding on the Taong wing. (ISA)

He cheated, riding in the wings of Taong so that it remains primed. (SSA)

The majority of readers who judge the characters in the fairy tale "BMR" as expected because of the similarity of the nature of the characters with humans, different characters, and the characters attached to the figures of birds are considered appropriate. This is seen in the following opinion quote.

The characters have characters such as human nature (ADS)

Some have good character, some are bad (CCR)

Characters in accordance with bird figures (RAK)

Readers who judge the characters are not as expected because the reader has his own imagination about the characters as contained in the following opinion quote.

I have my own imagination about the characters. (NFN)

The characters of Goroko and Cala Ibi are too predictable. (BT)

Each character in this fairy tale has a role that carries the message for the reader. Parrots have a wise and charismatic role, the usual role for leaders. Cala Ibi as ordinary people in the bird world has a role as an unyielding figure. He pursues dreams and tries to conquer challenges. Large birds are symbols of the rulers who determine the rules. Elang Darat and Elang Laut are symbolic figures of people who fight for the right people. Goroko is a symbol of the leader who neglects to take care of the people's mandate. This is in line with the opinion of Wolf (2004: 56) which states that figures in children's literature can be in the form of animals or plants, but these figures speak, think, and feel like humans. These figures according to Nurgiyantoro (2013:75) are intended to provide moral education. 
The ability of respondents to interpret the characters in "BMR" and how these characters can give moral messages to readers is in line with research conducted by Retno Purnama Irawati. Research with the title of Nilai-nilai Moralitas dan Budaya Asing dalam Sastra Anak Terjemahan melalui Pemaknaan Sastra Anak oleh Anak (Moral Values and Foreign Cultures in Children's Literature Translation through the Definition of Children's Literature by Children) discusses the characteristics of children's literary works that are circulating and popular among Indonesian children as well as the values of foreign morality and culture that are also carried in the works. translation of children's literary works according to the child's point of view as connoisseurs of children's literary translation. The results of this study indicate that respondents of children in all age groups are able to capture the values of morality and good culture contained in the story. The moral messages that emerge vary according to their own understanding and excitement after reading the texts of translated children's literary works.

The majority of respondents choose a style quote (how to use the specific language used by the author) that can facilitate the story related to the diction of imagery as contained in the following quote.

"See! A piece of sky! "Exclaimed a parrot. The herd of parrots perched at the root of the tree then shouted. The atmosphere was chaotic again. Big birds chided in disbelief. Other birds flock to admire the langit sky piece'. (Kristanti \& Pinurbo, 2015: 50)

A bit of sky skin or a sky chip is a connotative diction that is a symbol as a condition for proving the strength of the contestants in conquering the height of the sky. A condition that is put forward when the race will start. No bird knows the form of the skin of the sky. Therefore, when Cala Ibi dropped the bark of the mahogany tree after the race was finished, the birds thought it was sky skin. The sky skin symbol which is the "chip" of the sky is in line with Sayuti's opinion (2017:190) which reveals that the symbol is identical to the sign or symbol of a shape, motion, color, sound, or smell.

In addition to connotative diction of a bit of sky skin or sky pieces, respondents also chose denotative diction related to medical terms as contained in the following quote.

... A number of birds reported to Cockatoo, they resigned for reasons that do not make sense - some claimed to suffer from phobia of elevation, or suffer from vertigo, have a history of hypertension, cardiovascular, epilepsy when in fact they were only afraid (Kristanti \& Pinurbo, 2015: 47)

Denotative diction phobias, vertigo, hypertension, cardiovascular disease, and epilepsy are divisions that look difficult in the eyes of the child reader. Even so, the use of this diction can actually cause a 'funny' effect because these diseases are commonly suffered by humans in addition to being able to enrich vocabulary mastery.

Styles that can develop the imagination of the reader, the majority of respondents selected in the following quote.

Farther up, when the face of the earth was no longer visible to be covered with thick clouds, there were only a few remaining large-bodied and sturdy winged birds that remained. They began to feel tired, the Taong bird was no exception. His wings like heavy machinery sounded weak. $\mathrm{He}$ is not strong anymore and does not want to force yourself (Kristanti \& Pinurbo, 2015: 47)

Readers who have experience on an airplane will easily link the experience with the story above. The reader will imagine a situation when there is between clouds and can no longer see land. The imagination of the reader will develop by imagining the figure of Cala Ibi who also feels the fatigue of Taong, the bird he is riding.

In that terrible silence he could feel every flicker and flutter of his red wings, the pull of his joints and shoulders, all the bones and feathers. His entire form seemed to melt into the field as if he no longer had a physical perimeter, until for a moment he felt like he was the sky. Himself, the sky, the clouds, the two eagles, the red flower petals and the honey, the forest ... all merely the physical appearance of light from the highest edge of the veil. An edge that he no longer wants to reach. From here the throne of the king and all the beautiful nests no longer has any meaning. (Kristanti \& Pinurbo, 2015: 49)

The imagination of the reader develops even more when Cala Ibi is at the height of the sky. Cala Ibi had abandoned his arrogance because he felt that being king was no longer his goal. In fact, everything that is considered beautiful on earth, is nothing when you feel the height of flying in the sky.

The majority of respondents answered the style in the fairy tale "BMR" as expected because the language used by the author is easy to understand and not boring as contained in the following opinion quote.

Author's style makes the story more interesting and develops imagination (ASH)

Language uses everyday language, easy to understand (MS)

Style is not boring, want to continue reading (FAD)

The theme chosen by the majority of respondents is struggle. This is reinforced by the quotations chosen by the following respondents.

The Cala Ibi bird looked up, there was a Taong that was flying at a pace with black wings that stretched wide mighty, did not look tired. Cala Ibi exerted his last remaining strength, swooped down to the large bird and skillfully landed on a black feathered back. A feather on the back of the Taong bird is even bigger than the size of the Cala Ibi bird. Taong bird did not feel there was a ride on his back. (Kristanti \& Pinurbo, 2015: 47)

Sayuti (2017:199) revealed that the theme is something that will be fought through fiction. The base of the theme is the reason for the character's actions or motives. If you see Cala Ibi's motives at the beginning of the story, he wants the king's throne to fall into his hands. Therefore, all efforts (struggles) are made to achieve it. From looking for objects (reddish mahogany skin) that can be recognized as pieces of the sky to ride on the back of the mighty Taong bird in order to save energy at high altitude. Although, in its development Cala Ibi no longer concerned the king's throne, he continued to struggle by trying to escape from the safekeeping of Goroko birds when large birds determined he was a suspect of lying to bird society. The struggle continues at the end of 
the story through the narrative of the author who said that Cala Ibi might have flown to the sky and did not want to return to earth.

The majority of respondents who rated the theme in the fairy tale "BMR" as expected because the theme inspired and gave a good message to the reader. This is seen in the following opinion quote.

Themes can develop imagination and inspire (ASH)

The theme teaches something good that we can take his message (ADS)

The theme teaches to be honest (MDN

Factors that influence students' responses both positively and negatively to the fairy tale "BMR" are influenced by internal and external factors. Based on the respondents 'identities, it can be seen that the majority of respondents are 14 years old, the majority are Muslim, the majority are female, the majority are private fathers' jobs, the majority of mothers are unemployed, the majority of fathers and mothers last education is high

Table 2. Factors Influencing Students in Responding The Tale of "BMR"

\begin{tabular}{|c|c|c|c|}
\hline No. & STATEMENT & OPTION & AMOUNT \\
\hline \multirow[t]{2}{*}{1} & \multirow{2}{*}{$\begin{array}{l}\text { Parents often } \\
\text { motivate } \\
\text { respondents to } \\
\text { read literature }\end{array}$} & Yes & 55 \\
\hline & & No & 64 \\
\hline \multirow[t]{2}{*}{2} & \multirow{2}{*}{$\begin{array}{l}\text { Closest friends } \\
\text { have a habit of } \\
\text { reading } \\
\text { literature }\end{array}$} & Yes & 55 \\
\hline & & No & 64 \\
\hline \multirow[t]{2}{*}{3} & \multirow{2}{*}{$\begin{array}{l}\text { Respondents } \\
\text { spend more time } \\
\text { reading than } \\
\text { watching } \\
\text { television and } \\
\text { social media } \\
\text { (twitter, } \\
\text { facebook, } \\
\text { instagram, line, } \\
\text { whatsapp, etc.) }\end{array}$} & Yes & 28 \\
\hline & & No & 91 \\
\hline \multirow[t]{3}{*}{4} & \multirow{3}{*}{$\begin{array}{l}\text { The time spent } \\
\text { by respondents } \\
\text { to watch } \\
\text { television in a } \\
\text { day }\end{array}$} & $\begin{array}{c}0-30 \\
\text { minutes }\end{array}$ & 24 \\
\hline & & $\begin{array}{c}30-60 \\
\text { minutes }\end{array}$ & 43 \\
\hline & & $\begin{array}{c}>60 \\
\text { minutes }\end{array}$ & 52 \\
\hline \multirow[t]{3}{*}{5} & \multirow{3}{*}{$\begin{array}{l}\text { The time spent } \\
\text { by respondents } \\
\text { to access social } \\
\text { media in a day }\end{array}$} & $\begin{array}{c}0-30 \\
\text { minutes }\end{array}$ & 10 \\
\hline & & $\begin{array}{c}30-60 \\
\text { minutes }\end{array}$ & 25 \\
\hline & & $\begin{array}{c}>60 \\
\text { minutes }\end{array}$ & 84 \\
\hline \multirow[t]{4}{*}{6} & \multirow{4}{*}{$\begin{array}{l}\text { Number } \\
\text { fables read }\end{array}$} & $0-5$ & 49 \\
\hline & & $6-10$ & 27 \\
\hline & & $11-15$ & 13 \\
\hline & & $>15$ & 30 \\
\hline 7 & Respondents are & Yes & 52 \\
\hline
\end{tabular}

\begin{tabular}{llll}
\hline & \multicolumn{1}{l}{ often told by } & No & 67 \\
parents when & & \\
they are young & & \\
\hline 8 & $\begin{array}{l}\text { Respondents are } \\
\text { still reading } \\
\text { fairy tales }\end{array}$ & Yes & 46 \\
\hline 9 & $\begin{array}{l}\text { Respondents } \\
\text { were more } \\
\text { interested in } \\
\text { watching a } \\
\text { fairytale show } \\
\text { than reading } \\
\text { themselves }\end{array}$ & & \\
\hline 10 & $\begin{array}{l}\text { Respondents } \\
\text { prefer fairy tales } \\
\text { in the form of } \\
\text { animated films } \\
\text { rather than } \\
\text { writing }\end{array}$ & \\
\hline
\end{tabular}

In connection with the opinion expressed by Jauss (in Junus, 1985:104) regarding the expectation horizon that is the experience of the reader, the majority of respondents answered that they did not get motivation from their parents. The majority of respondents' closest friends did not have the habit of reading literature. The majority of respondents answered that they no longer read fairy tales. The majority of respondents answered that they only read 0-5 stories.

This shows how big the role of the family, in this case parents, for the growth of interest in reading literature towards children. Parents who have a penchant and reading habits will be a model for children. Habits made by parents such as having the time required to read literature, visit the library, and set aside funds to add to the collection of literary reading material into a "warning" for children to follow these habits. Conversely, if parents do not have a familiarity with literary books, it is not surprising that even children will be far from the world of literature. If the foundation of the family to love literature is strong, even though closest friends do not have the habit of reading literature, children will not be affected.

The majority of respondents answered spending more time watching television and social media (Twitter, Facebook, Instagram, Line, WhatsApp, etc.) than reading. This is supported by the subsequent statement that the majority of respondents spend more than 60 minutes a day watching television and accessing social media. This fact answers the justification for the surveys that have been done related to the familiar habits of children with the world of television and the internet rather than the world of books. The childhood habits of the majority of respondents are not often told by parents to influence this behavior. The majority of respondents are more interested in watching a fairy tale show than reading themselves and prefer fairy tales in the form of animated films rather than writing. 


\section{CONCLUSION}

The plot, character, style, and theme of the fairytale "Burung-burung Memilih Raja" received a positive response from readers. This is known through a positive response to the plot with the beginning of the story that makes the reader want to know the sequel, the surprising part of the series of stories, and the end of the story that is not easy to guess. The characters are clearly described, similar to human life, and are able to inspire readers to do good things. The figure of Cala Ibi is considered as an inspiring figure because he has a character that is unyielding, clever, and humble. Goroko figure is considered as an inspirational figure because of neglect. Style helps understand stories and develop imagination. The theme of struggle as a fairy tale theme is found in life and is able to reveal the truth of the author's ideas, attitudes, and outlook on life.

Internal factors that influence student responses indicate that there is limited literary reading experience and limited listening or watching fairytale experience. External factors show the lack of motivation from parents to read literature, the lack of influence of friends who are accustomed to reading literature, and the magnitude of the influence of television and social media.

These two things show that when the fable which was originally formed was oral literature and then became written literature in the middle of a generation that is experiencing a reading crisis, the tale makes a positive contribution. In an era when young people play an important role in media technology, fairy tales can be presented in forms and characters that suit their conditions. This at the same time transformed the lazy reading community into a community of need.

\section{REFERENCES}

Irawati, Retno Purnama. Nilai-nilai moralitas dan budaya asing dalam sastra anak terjemahan melalui pemaknaan sastra anak oleh anak. Lingua. UNS, Semarang, edisi IX (1) 2013.

Junus, Umar. (1985). Resepsi sastra. Jakarta: Gramedia.

Killpatrick (1994). Books that build character: A guide to teaching your children moral values through stories. New York: Touchstone.

Kristanti, Dhenok \& Joko Pinurbo (ed.). (2015). Dongeng Negeri Kita. Jakarta: Padasan.

Nurgiyantoro, Burhan. (2013). Sastra anak pengantar pemahaman dunia anak. Yogyakarta: Gadjah Mada University Press.

Sayuti, Suminto A. (2017). Berkenalan dengan prosa fiksi. Yogyakarta: Cantrik Pustaka.

Segers, Rien T. (2000). Evaluasi teks sastra. Yogya- karta: Adicita Karya Nusa.

Stanton, Robert. (1965). An introduction to fiction. New York: Holt, Rinehart and Winston.

Teeuw, A. (1984). Sastra dan Ilmu Sastra. Jakarta: Dunia Pustaka Jaya.

Wolf, Shelby A. (2004). Interpreting literature with children. New Jersey:

Lawrence Erlbaum Associates.

